UDK 341.63:339.727.22

DOI: $10.5937 /$ RKSPP2102149Z

UROŠ ŽIVKOVIĆ

\title{
INVESTMENT ARBITRATION AND THE MFN CONUNDRUM - THE LONG AND WINDING ROAD FROM MAFFEZINI TO IÇKALE
}

Interpretation of the most-favored nation clause in investment treaty arbitration has been sparking debates for the better part of two decades. The paper examines the issue from the perspective of two opposing ends - a broad stance of the seminal decision in Maffezini Case and a recent more restrictive approach undertaken by the arbitral tribunal in Içkale decision, in order to paint in broad strokes the outlines of a balancing act mechanism in interpretation that author puts forward.

Key words: investment arbitration, MFN, BIT, Maffezini

\section{N T R O D U C T I O N}

Relationships between foreign investors and host states develop on a promise that an investor in the economy of the host state will enjoy treatment on a non-discriminatory basis, adequate legal protection, and economic benefits of its investment. The scope of the promises given - just like the actual readiness and ability of the host state to keep them - will, to a large extent, structure the relationship with the investor and set the theme for the outcome of the investment project. This is one of the reasons why developing economies perceive it

Uroš Živković, LLM (Cantab), Returning Point Circular Migration Project Expert within the United Nations Development Program (Serbia), e-mail: uros.zivkovic@tackapovratka.rs. 
as essential to set a level playing field for businesses and traders coming from different countries, avoiding the risk of being exposed to costly dispute settlement procedures with an unsatisfied investor. ${ }^{1}$

In terms of promises given to attract foreign capital, host states predominantly ensure the existence of equal opportunities for investors in a two-fold manner: by guaranteeing treatment not less favourable to that of domestic investors (standard of national treatment, NT clause) and by awarding the substantive treatment offered to other third-state investors by virtue of the most-favoured-nation standard (MFN treatment). Naturally, the full spectrum of protection of foreign direct investment encompasses a larger portion of different treatments and benefits; however, these fall outside the scope of the present paper. ${ }^{2}$

Although the guarantees of the national and MFN treatment can be found within host state's national laws or codifications promoting and protecting foreign direct investments, the usual framework for their incorporation is within a particular bilateral investment treaty (hereinafter: BIT). ${ }^{3}$ By way of an MFN clause in a BIT, an investor can benefit from a wider spectrum of substantive protection, in a situation where third-state foreign investors or domestic investors are in effect granted a benefit by the host state. While national and MFN treatment provisions have parallel structures, similar purpose and have become an integral part of most modern BITs, it is clear from the treaty interpretation practice of investment tribunals that the issues of scope and nature of the MFN clauses in particular, have raised considerable practical and doctrinal issues.

1 Majority of disputes settled between the investor and the host state is resolved by means of arbitration - see Christoph Schreuer, "Travelling the BIT Route of Waiting Periods, Umbrella Clauses and Forks in the Road", The Journal of World Investment and Trade, Geneva, 2004, 231.

2 For a more detailed account of the overall structure of the BIT see Surya P. Subedi, International Investment Law - Reconciling Policy and Principle, Oxford \& Portland, 2008, 84; Stephan W. Schill, "Multilateralizing Investment Treaties through Most-Favored-Nation Clauses", Berkeley Journal of International Law, Vol. 27, No. 2, 2009, 498.

3 The added value of the MFN or NT clauses in national laws of host-states exists in cases where the foreign investor or its investment are not protected by a bilateral or multilateral treaty that contains these provisions. Nonetheless, the fact that national laws can be unilaterally changed, amended or suspended by the host state (unlike international treaties) raises the level of uncertainty for foreign investors, thereby providing BIT incorporation of these standards as preferable, see Yas Banifatemi, "The Emerging Jurisprudence on the Most-Favoured-Nation Treatment in Investment Arbitration", Investment Treaty Law: Current Issues III: Remedies in International Investment Law: Emerging Jurisprudence of International Investment Law (Eds. A. K. Bjorklund, I. A. Laird, S. Ripinsky), British Institute of International and Comparative Law, London 2008, 241-273. 
Departing from the classical Most-Favoured-Nation concept, foreign investors have time and time again tried to rely on the MFN clause in order to eliminate certain procedural steps and proceed directly with arbitration under a diagonal clause in a BIT, opt for a different arbitral venue from the one offered under the applicable BIT, expand tribunal's jurisdiction ratione materiae or ratione personae by relying on a broader definition of the investment/investor in a BIT concluded between a host state and a third state, procedurally stretch the confines of the dispute by pursuing contract claims through an umbrella clause from another BIT or just simply go beyond the borders of the underlying BIT containing the MFN clause. Plethora of different (and often diverging) approaches taken by investment tribunals in the past two decades in deciding upon the preceding issues shows that the topic of consistent interpretation of MFN clauses in investment treaty arbitration is far from settled. In words of Mr. Zachary Douglas, "there is a high premium on certainty when it comes to rules for the adjudication of disputes", as investors are not ready and keen to explore alternatives in the form of national and usually inapt courts of the host state through domestic litigation. ${ }^{4}$ The inconsistency in understanding and application of the MFN clauses systematically undermines practitioners' chances to predict the potential outcomes of a dispute while at the same time provides international scholars with certain unease when dealing with issues of BIT interpretation. The MFN conundrum has also sparked significant debates related to actual need for re-negotiating existing BITs regimes and providing more clarity on the wording of the MFN clauses - causing stir in places where water was previously still.

Thus, the focal point of research and analysis conducted in this paper revolves around the diverging nature of the MFN clauses in investment treaty arbitration, their interpretation and actual scope from a procedural and substantive perspective of a dispute - looking specifically at the evolution of interpretative stances from the pivotal Maffezini case to a more recent Içkale v. Turkmenistan decision. The research has, in general, indicated that some of the questions investment tribunals have posed in the past when approaching claims raised by parties pertaining to a more creative application of the MFN clause have been formulated in a way that contributed towards uncertainty and inconsistency in interpretation as such. It can be inferred from the practice and scholarly writing that lack of consensus in interpretation of the MFN clauses stems from inadequate reliance of tribunals on previous practice without distinguishing the matters of general treaty interpretation and specific, factual, case-sensitive scenarios. Nonetheless, the case law of

4 Zachary Douglas, “The MFN Clause in Investment Arbitration: Treaty interpretation Off the Rails", Journal of International Dispute Settlement, Vol. 2, No. 1, Oxford, 2011, 98. 
MFN interpretation in arbitral practice from early 2000's to today has shown a shift in from a trend of broad application to a more nuanced and clause-specific decisions making which is the tendency the author of the paper fully endorses.

\section{NAVIGATING THE MFN STANDARD}

\section{History and Origins}

Contemporary international law has defined the MFN treatment as treatment accorded by the granting State to the beneficiary State, or to persons or things in a particular relationship with that State, not less favourable than treatment extended by the granting State to a third State or to persons or things in the same relationship with that third State..$^{5}$ Equality and universality of treatment that the MFN clause aims at establishing is a consideration accorded by states that willingly commit to non-discriminative approach in their dealings. It is to be noted, however, that despite being regarded as the "central pillar of trade policy for centuries" application of the MFN treatment is conditional on existence of a binding clause in a treaty. ${ }^{6}$ As aptly stated in practice and doctrine, MFN treatment is not required under customary international law. ${ }^{7}$ As such, the interpretation, its extent as well as the rights and obligations arising out if its application will also depend on the particular wording of the clause incorporating the MFN treatment.

Prior to conceptualization of the modern definition, the MFN standard in the international treaty making developed gradually. From a historical perspective, the original notion of the treatment can be found in the mediaeval treaties. Special Rapporteur for the ILC, Mr. Endre Ustor, suggests that the earliest appearance of

5 See Article 5 of the Draft Articles on Most-Favoured-Nation Clauses, ILC Draft in Yearbook of the International Law Commission, Vol. II, Part Two, New York, 1978, 21 (hereinafter: Draft Articles on MFN); also Stephen Fietta, "Most Favored Nation Treatment and Dispute Resolution under Bilateral Investment Treaties: A Turning Point?", International Arbitration Law Review, No. 4, 2005, 131-132.

6 Marie-France Houde, Fabrizio Pagani, "Most-Favored-Nation Treatment in International Investment Law", OECD International Investment Law: A Changing Landscape, Paris, 2005, 129.

7 See Article 7 of the Draft Articles on MFN, supra note 5, that stipulates: "nothing in the present articles shall imply that a State is entitled to be accorded most-favoured-nation treatment by another State otherwise than on the basis of an international obligation undertaken by the latter State"; see also Rudolf Dolzer, Christoph Schreuer, Principles of International Investment Law, Oxford, 2012, 206; Andrew Newcombe, Lluís Paradell, "Chapter V - Most-Favored-Nation Treatment", Law and Practice of Investment Treaties: Standards of Treatment, The Hague, 2009, 194. 
the rudimentary MFN standard treatment in Europe dates back to XI and XII century and can be traced in agreements concluded between guilds, merchants and mediaeval trading cities in France, Spain and Italy. ${ }^{8}$ Probably one of the first documented occurrences of an MFN-like treatment clause was in a Treaty for Mercantile Intercourse with Flanders signed between King Henry V of England and Duke John of Burgundy in Amiens on 17 August 1417 that accorded English vessels the right to use the harbors of Flanders in the same capacity as French, Dutch, Sealanders and Scots. ${ }^{9}$ Albeit conditional and narrow, as it granted comparable treatment on a very limited national basis, the MFN treatment in the Treaty for Mercantile Intercourse with Flanders from 1417 was a starting point for development of the underlying reciprocal, non-discriminatory rationale.

By keeping the mercantile powers in the imperial Europe and on equal level with one another in terms of trade with rare commodities, spices and goods from the colonial lands, reciprocal nature of the MFN treatment started blossoming into an idea that will become one of the most essential standards in investment protection in the $21^{\text {st }}$ century. As it has been underlined by the ICJ in the context of the early investment treaties, the very purpose of the MFN treatment was to "establish and to maintain at all times fundamental equality without discrimination among all of the countries concerned". 10 The early, conditional nature of the MFN clause however evolved through time and gradually found its way into modern treaty making, expanding to become one of the fundamental unconditional mechanics of international economic relations.

This is also how development ideas embodied in the Havana Charter from 1948 when signatory parties have pledged to structure policies and their relations in a way that would avoid discrimination among foreign investors influenced wide incorporation of the MFN clauses in BITs and multi-lateral treaties concluded after 1950 's. ${ }^{11}$ At that time, it was suitably noted by the widely cited Prof Georg

8 Endre Ustor, "First Report on the Most-Favoured Nation Clause", Yearbook of the International Law Commission, Vol. 2, UN Doc. A/CB.4SERA/1969/Add. 1, New York, 1969, 159.

9 United Nations Conference on Trade and Development (UNCTAD), "Most-FavouredNation Treatment", UNCTAD Series on Issues I International Investment Agreements I, New York, 1999, 13; see also Martin Molinuevo, "Post-establishment MFN and NT Obligations", Protecting Investment in Services: Investor-State Arbitration versus WTO dispute Settlement (Ed. Martin Molinuevo), Global Trade Law Series, Vol. 38, The Hague, 2011, 93.

10 Case Concerning Rights of Nationals of the United States of America in Morocco (France v. US) (1952) ICJ Rep 176, 192.

11 See Article 12 of the Havana Charter for an International Trade Organization; United Nations Conference on Trade and Employment, Final Act and Related Documents, April 1948; for a more detailed account of negotiations and formation of the core ideas leading to the Havana Charter see 
Schwarzenberger that overarching purposes of the MFN treatment - if accepted by the signatory parties - is to ensure that "anybody's advantage accrues to everybody's profit". ${ }^{12}$ This underlying notion of equality and comparable status of investors coming from different states, coupled with the idea of close economic cooperation between the states that are signatories to the treaty is still reflected in the MFN standard, as its application provides for much needed uniformity in treatment and balances the competition on the market. ${ }^{13}$ The standard itself remains to be a relative one, as it will depend on how the host state treats other foreign investors and investments in its territory. That is probably one of many reasons why its conceptualization within treaties has been predominantly based in bilateral investment agreements, instead of multilateral arrangements. Development of international law clearly shows that granting benefits is always easier to agree upon when the number of the parties is relatively small.

Apart from the universally accepted definition of the MFN standard embodied within the framework of WTO, its application and interpretation in the field of foreign direct investment has been more prolific in the past two decades. ${ }^{14}$

\section{Modern Understanding of the MFN in International Investment Law}

Limitations to the MFN standard are mapped within the scope of the applicable BIT or multilateral agreement containing the clause. The MFN clause nowadays stands as a necessary mechanism of keeping the promises given by the host state towards foreign investors, eliminating the possibility of unequal treatment due to changes in the national legislation of the host state or subsequent changes introduced through other bilateral and multilateral treaties.

Richard Toye, "Developing Multilateralism: The Havana Charter and the Fight for the International Trade Organization, 1947-1948”, The International History Review, XXV. 2, 2003, 286-289 et seq.

12 Georg Schwarzenberger, "The Most-Favoured Nation Standard in British State Practice", British Yearbook of International Law, Vol. 22, No. 96, London, 1945, 99-100.

13 Pia Acconci, "Most-Favored-Nation Treatment", The Oxford Handbook of International Investment Law (Eds. Peter Muchlinski, Federico Ortino, Christoph Schreuer), Oxford, 2008, 354; United Nation Conference on Trade and Development (UNCTAD), "Most-Favored-Nation Treatment", UNCTAD Series on Issues in International Investment Agreements II, Geneva, 2010, 1, http://unctad. org/en/Docs/diaeia20101_en.pdf, 23.09.2021.

14 Most Favored Nation principle, albeit one of the cornerstones in the pantheon of WTO, is still subject to exceptions and concessions related to the different treatment in regional and free trade areas, developing counties and regional economic blocks. See for instance Kyle Bagwellm, Robert W. Staiger, "Multilateral trade negotiations, bilateral opportunism and the rules of GATT/ WTO", Journal of International Economics, Vol. 63, Issue 1, 2004, 1-29; Peter van den Bossche, Werner Zdouc, The Law and Policy of the World Trade Organization, Cambridge, 2013, 317 et seq. 
In the short run, the MFN clause in a BIT will be one of the incentives for a foreign investor to decide to invest, while over a longer period it will be a safeguard to balance out any potential discrimination that host-state might create by according benefits solely to investors and investments coming from other countries. For the state parties to a treaty, MFN clause will stand as a promise of non-discriminatory treatment towards foreign investors coming from different countries.

Taking into consideration that the basic idea behind the MFN treatment as a reciprocal mechanism has remained unchanged from the XV century till today, the application of the standard should come across as reasonably straightforward in the domain of foreign direct investment as well. And while general definition of the standard exists in scholarly writing and case law, many facets of treaty negotiations and individual relationships between the signatory states over the collage of numerous BITs concluded, guarantees large-scale differences in wording of the MFN clauses.

Admittedly, UNCTAD's monitoring from 2009 counts over 2650 reported BITs, majority of which stipulates the application of some form of MFN treatment. ${ }^{15}$ Furthermore, the unprecedented multiplication of the BITS once coupled with incoherent arbitral practice necessarily leads to diversification and often polarization of views on interpretation of the treaty provisions. If one considers that, in addition, certain volume of investment arbitral practice remains to be private and unpublished (under auspices of ad-hoc arbitral tribunals or institutional rules protecting confidentiality of the parties) the shape of the issue of interpretation of BITs in international investment law becomes even blurrier.

Prof. Alain Pellet in his 2013 Lalive Lecture paints the picture of how he sees jurisprudence in the field of investment arbitration:

"Let's just say that I think there exists 'some' jurisprudences constantes on a limited number of points ssome of which, is true, are important (such as recognition of ius standi of shareholders or the binding force of the provisional measures - two areas in which the Court has played the role)\} and an unfortunate jurisprudential mess on many others - eg with regard to the definition of investment, the consequences of most favored nation (MFN) clauses or umbrella clauses..." 16

15 Julie A. Maupin, "MFN-Based Jurisdiction in Investor-State Arbitration: Is There any Hope for a Consistent Approach?", Journal of International Economic Law, Vol. 14, No. 1, Oxford, 2011, 158.

16 Alain Pellet, "2013 LALIVE Lecture - The Case Law of the ICJ in Investment Arbitration", ICSID Review, Vol. 28, No. 2, 2013, 224 (underline emphasis in the cited text added by the author of this paper). 
The particularities of the incoherent adjudication in the field add an additional layer to the overall picture and set into motion one of the most discussed dilemmas in international investment law of today. However, if one ventures with a bit more legal heart and jurisprudential faith into the topic, the chaos takes shape of an interesting and vivacious carnival - many are shouting, some are having fun, music, sounds, and flavors are everywhere, atmosphere is at times overwhelming but if one focuses and listens carefully, finding a proper tune may nit be so Utopian.

In the meantime, many questions beg an answer: should MFN clauses be applied in connection to procedural mechanisms embodied within third party BITs and how should tribunals interpret them with more consistency? Is there a chance for a more uniform interpretation in the field in the near future? Can one deduce common factors from diverging jurisprudence on the matter? Will there be a multilateralization revolution in the area of foreign direct investment? The upcoming paragraphs will try to shed some light on these issues and provide a bit of a different insight into a topic.

\section{MFN INTERPRETATION AND INCONSISTENCIES}

As delineated in the preceding paragraphs, if a host state guaranteed a particular kind of treatment to foreign investments in any BIT, then at least in terms of substantive treatment it generally has guaranteed that treatment to investment covered by any BIT that contains an MFN clause. ${ }^{17}$ This however is a general understanding that should always be balanced with adequate interpretation of a particular clause in a specific treaty. This contextualisation, as the upcoming paragraphs will show, is crucial for adequate assessment of the MFN's scope.

\section{Erosive Logic of the Maffezini Case}

From investors' perspective, MFN clauses are there to synchronize the rules governing their economic activity and provide a more unified platform for investment protection in any given host State that bases its investment treaties on MFN treatment. ${ }^{18}$ As a "product of liberal expansiveness" of that period, seminal decision on objections to jurisdiction in the Maffezini Case in 2000 has reshaped

17 Kenneth J. Vandevelde, Bilateral Investment Treaties: History, Policy and Interpretation, New York, 2010, 349-350.

18 Stephan W. Schill, op.cit, 518; see also M. Sornarajah, The International Law on Foreign Investment, Cambridge, 2010, 204. 
the way MFN clauses have been analysed and opened numerous floodgates for interpretation that are at the centrefold of this paper. ${ }^{19}$ Many authors are still not in sync as to whether the impact of this decision was for better or worse: however, just like other cases that left the mark - this one will be inspected in a bit more detail.

By way of background, claimant in the case - Argentinian citizen Emilio A. Maffezini - initiated proceedings (in the capacity of a foreign investor) against the Kingdom of Spain, before an ICSID tribunal pursuant to the mechanism envisaged within the Argentine-Spain BIT. The basic BIT in question provided for ICSID arbitration as an available mechanism for dispute settlement with a procedural precondition. Namely, the investor was obliged to pursue its claims before national courts of the host state and in case the litigation proceedings remain unresolved after 18 months, investor would be allowed to instigate proceedings before an investment tribunal. The BIT was very specific in this regard and provided the 18 months period as a procedural step that needs to be undertaken by the investor seeking redress before international arbitration. With the objective to surpass the 18 months period of litigating - aiming to apply more favourable conditions from the Spain-Chile BIT - Maffezini relied on the MFN clause in the Argentine-Spain BIT that read:

"In all matters subject to this Agreement, this treatment shall not be less favorable than that extended by each Party to the investments made in its territory by investors of a third country." 20

Before we turn to analysis of the decision of the Tribunal, two notions need to be made clear. Reliance on the MFN clause to seek incorporation of a substantive treatment from another BIT is a classical MFN scenario and has not been regarded as problematic in and of itself. These substantive issues could range from importation of a full protection and security standard to protection against the denial of justice. ${ }^{21}$ Moreover, every investor has the interest in obtaining a more favourable status in relation to the host state - within or outside the scope of a dispute. However, what Maffezini sought was that the operation of the MFN clause in the Argentine-Spain BIT provides for application of a different procedural precondition from another BIT concluded by the host state (Chile-Spain BIT), as investors from third country (Chile) have a favourable standing compared to that of investors

19 See M. Sornarajah, op.cit, 322; the case referred to is Emilio Augustin Maffezini v. The Kingdom of Spain, Case No. ARB/97/7, Decision of the Tribunal on Objections to Jurisdiction, 25 January 2000, [hereinafter: Maffezini Case].

20 Maffezini Case, 38.

21 See for instance Ambatielos Case, Merits, Judgment 19 May 1953; also see Bershader Case, SCC Case No. 080/2004, Award, 21 April 2006, 179. 
coming from Argentina. In this particular instance, investors from Chile had no precondition of litigating before domestic courts in Spain but only had to satisfy the six months negotiation period before commencing arbitration. On these facts, and upon request of Maffezini, Tribunal has infamously decided as follows:

"From the above considerations it can be concluded that if a third-party treaty contains provisions for the settlement of disputes that are more favorable to the protection of the investor's rights and interests than those in the basic treaty, such provisions may be extended to the beneficiary of the most favored nation clause as they are fully compatible with the ejusdem generis principle [...] This operation of the most favored nation clause does, however, have some important limits arising from public policy considerations that will be discussed further below. "22

The preceding paragraph easily demonstrate that Maffezini tribunal has considerably departed from the rooted context of the MFN standard by concluding that the MFN clause from the Argentine-Spain BIT can be stretched so as to provide the investor with a possibility to resort to a different, more favorable procedural mechanism from another BIT accrediting this to the wording of this particular clause as well as the will of the state parties that can be inferred from the treaty. Loosely interpreting the "broad" notion of the term treatment in the MFN clause, Maffezini tribunal eroded the basic concepts of treaty interpretation. Nevertheless, the objective reasoning of the Maffezini tribunal and the general language of the award transmits the message very clearly and convey the stance with a decent level of certainty. The problems arise once the surface is being scratched.

In line with this, taking a closer look at the rest of the award the tribunal expanded its creativity and outlined certain limitations in interpretation of MFN clauses for the future reference - compiling the list of issues of public policy reasons that cannot be surpassed (stating among others exhaustion of local remedies or fork-in-the-road provisions) ${ }^{23}$ Unfortunately, it remains unclear where do these limitations originate from - as they are not contained in the underlying BIT or its travaux préparatoires and cannot in any way be regarded as general policy reasons. Many authors have expressed concerns for these unexplained gaps or reasoning in tribunal's argumentation, while certain arbitrators clearly opted to depart from the Maffezinis logic in their future work. ${ }^{24}$ Nonetheless,

\footnotetext{
22 Maffezini Case, 56.

23 Ibidem, 62-64.

${ }^{24}$ See for instance Dana H. Freyer, David Frelihy, "Most-Favored-Nation Treatment and Dispute Settlement in Investment Arbitration: Just How "Favored" is "Most-Favored"?" ICSID Review
} 
a certain number followed the Maffezini reasoning which jointly wit the previous group of "dissidents" caused diversification of interpretations of a single standard in international law. ${ }^{25}$

It can be said that the dispute resolution provisions in the BIT belong to the very core of what an investment treaty signifies for an investor. As such, they are an integral part of the mosaic and an essential element in enforcement of investor's rights. Maffezini-an logic takes this mantra as a light motive in its arguments that support their view of interpretation and expansion of the MFN clause. However, this in itself does not justify the usage of the most favored nation clause as a general mirror to reflect every aspect of a BIT concluded between the host and a third state. This is specifically the case when states, parties to the BIT, have not defined in specific terms the scope of the MFN clause and when centuries of state, court and arbitral practice never provided for a ground for MFN clauses applied to procedural and jurisdictional issues of international treaties.

At the time of the conclusion of the Argentine-Spain BIT, the states could not have envisaged that the MFN standard from their BIT would at a certain point in time allow investors to bypass limitations imposed within the dispute resolution clause, as the Maffezini was the first reported dispute that directly dealt with this topic. Interpreting the MFN clause from that BIT in such a loose manner could have only been understood as going against the will of the parties to the treaty, not in line with it.

Furthermore, the dilemma is whether essential difference between the procedural issues of jurisdiction of the tribunal and substantive obligations of investment protection in the treaty can be surmised that would ban the application of the MFN clause in the way Maffezini tribunal did. ${ }^{26}$

Certain tribunals how concurred to the opinion of the Maffezini arbitration, and following the same factual pattern, claimant in the Siemens Case has successfully invoked the MFN clause from the Germany-Argentina BIT and overcame the 18-month litigation-first procedural precondition for initiation of desired arbitral proceedings. The case was resolved under the auspices of ICSID, and despite the different and novel approach that Argentine has employed in the course

- Foreign Investment Law Journal, Vol. 20, Issue 1, 2005, 67; see Plama Consortium Limited v. Republic of Bulgaria, Case no. ARB/03/24, Decision on Jurisdiction, 8 February 2005 [hereinafter: Plama Case].

25 Siemens A.G. v. The Argentine Republic, Case No. ARB/02/8, Decision on Jurisdiction, 3 August 2004, 79 et seq. [hereinafter: Siemens Case].

26 Zachary Douglas, The International Law of Investment Claims, Cambridge, 2009, 345. 
of the dispute, attempting to differentiate from the Maffezini situation ${ }^{27}$, the tribunal allowed the claimant to continue with the proceedings before the panel despite the fact that the very wording of the MFN clause in the basic treaty was narrower than the one in the Maffezini. On similar wings, arbitral tribunal in Gas Natural Case ${ }^{28}$ rendered a decision validating the Maffezini approach on accepting the change in arbitral procedure, based on the effect of the MFN clause in the basic treaty that encompasses dispute resolution provisions.

It is clear that both tribunals reinstated the importance of the dispute resolution mechanism as a quintessential part of the BIT - and as such, perfectly fit to be brought to life through a MFN clause. Polishing the procedural aspects of the dispute resolution mechanism and providing for a different, shorter and more expedient approach fully reflects what every investor wants to achieve. However, interpretative stance applied to the MFN clauses in these cases falls short of substantial insight into the real nature of the MFN standard.

\section{Divergence from the Maffezinian Paradox}

Different approach in analysing the request of the investor to utilise the MFN treatment in such way as to gain access to a dispute resolution mechanism that is not incorporated in the original treaty was attempted in Plama Consortium v. Bulgaria. Cypriot investor asserted two separate bases for jurisdiction - one under the Part V of the Energy Charter Treaty and one under the 1987 Bulgaria-Cyprus BIT. The real problem arose with the original BIT that called for ad hoc UNCITRAL arbitration entitled solely with the power to decide on the amount of compensation (once the breach is confirmed by national authorities, i.e. domestic court). The claimant nonetheless attempted to resort directly to ICSID arbitration under the BIT that was signed between Bulgaria and Finland (Bulgaria-Finland BIT), through the loophole of the MFN clause in the BIT. The attempt was futile, as tribunal rightfully acknowledged that:

"Dispute resolution provisions in a specific treaty have been negotiated with a view to resolving disputes under that treaty. Contracting States cannot be presumed to have agreed that those provisions can be enlarged by incorporating dispute resolution provisions from other treaties negotiated in an entirely different context. " 29

27 Siemens Case, 51-53.

28 Gas Natural SDG, S.A. v. The Argentine Republic, Case No. ARB/03/10, Decision of the Tribunal on Preliminary Questions on Jurisdiction, 17 June 2005 [hereinafter: Gas Natural Case].

29 Plama Case, 207. 
In addition, the arbitral tribunal has been very adamant in completing the argument on why MFN clause in this particular scenario cannot be understood as encompassing dispute resolution provisions from another BIT. The tribunal has skilfully distinguished between the existing cases that supported Maffezini's stance and the situation that it was facing at that time. Additionally, it expressly critiqued Siemens award. This is predominantly so because of the focus of the claimant's request. Unlike Siemens, Gas Natural and Maffezini, the investor requested to use not just a benefit in procedure that is the same (in essence) as the procedure in the original BIT, but to incorporate a completely new mechanism of ICSID rules (compared to the original ad hoc arrangement) through the operation of the MFN clause. One additional point that was stressed in the decision and that stands as a complete departure from the Maffezini is that silence in the MFN clause on issues of dispute settlement does not allow one to presuppose that the clause will be deemed to have incorporated the dispute settlement provision.

Following the strict line of interpreting consent of a host state to be bound by the jurisdiction of an arbitral tribunal, the panel in the Wintershall Case ${ }^{30}$ not only confirmed the standing of the Plama tribunal, but took a complete detour from the interpretation of the relevant clauses of the Germany-Argentina BIT, and contrary to Siemens Case rejected application of the MFN clause to dispute settlement provisions. Using the same body of the Argentina-Germany BIT, but a completely different approach from the one employed by the Siemens tribunal, Wintershall panel has very meticulously explained how the consent of the host state is inextricably intertwined with all the procedural steps that need to be undertaken by the investor in order to gain access to the ICSID arbitration. Without the adequate approach in dealing with this, investors would easily impede upon the carefully designed dispute resolution mechanism and this would go completely against the will of the contracting parties to the treaty.

\section{Importance of Wording and Contextualisation}

Maffezini decision opened doors to interesting discussions on the topic of MFN clauses, their nature, purpose and scope, while influencing divergence in case law on the matter. As prompted by late Prof Gaillard, Maffezini brought into light the unlikely interaction of the MFN treatment with issues of jurisdiction

30 Wintershall Aktiengesellschaft v. Argentine Republic, ICSID Case No. ARB/04/14, Award, 8 December 2008 [hereinafter: Wintershall Case]. 
- opening floodgates to questions that may arise at their intersection. ${ }^{31}$ All of these issues become additionally complicated in situations where unclear wording of the MFN clause provides leeway for different schools of interpretation to take charge. These approaches can be potentially harmful as they shed the light on only one aspect of the clauses in question, focusing on the phrasing rather than the purpose, nature and overall context. What is more, the reason why many tribunals failed to address the issue of whether the MFN clause is in general suitable to cover issues that are characterised as procedural or pertaining to jurisdiction is because the arbitral panels would rather focus their attention on plain wording than true meaning.

It seems, in any event, that wording of the clause may be of help and play a significant role in at least two distinct scenarios. Firstly, there are a certain number of cases when the MFN clause will define the scope of its application be either expressly excluding provisions on dispute settlement from its reach or directly attaching its application to treatment in the BIT that encompasses dispute settlement provisions. ${ }^{32}$ These situations are for the better part product of negotiations and amendments to BIT arrangement between the states after the Maffezini was published and legislators and governments realized that damage control could be performed. A series of UK BITs concluded in the first decade of the $21^{\text {st }}$ century (including the underlying inspiration - the 2005 Model UK BIT), expressly include the dispute settlement mechanism provision within its scope. ${ }^{33}$ Secondly, if the MFN clause is worded in such a particular manner that it enumerates areas and scope of its application exhaustively (leaving or including dispute resolution

31 See the list of hypothetical questions that late Prof Gaillard raises - from incorporation of dispute settlement mechanisms into treaties that previously had none, to extension of the jurisdiction through operation of the MFN clause - Emmanuel Gaillard, "Establishing Jurisdiction Through a Most-Favored-Nation Clause”, New York Law Journal, Vol. 233, No. 105, New York, 2005, 3.

32 Howard Mann, Konrad von Moltke, Luke Eric Petersen, Aaron Cosbey, IISD Model International Agreement on Investment for Sustainable Development: Negotiators' Handbook, Winnipeg, 2006, -14-15 defined the issues, excluding application of the MFN clause: "The use of the word "substantive" and its accompanying footnote ensure that only the substantive provisions of any future agreement will be subject to the MFN rule, not dispute settlement provisions or procedures that might be specifically established in a bilateral or regional context."

33 See Article 3 (3) of the 2005 (with 2006 Amendments) Draft Agreement Between The Government of The United Kingdom of Great Britain and Northern Ireland and The Government of [Country] for The Promotion and Protection of Investments, Appendix 10, 561, see also Article 3 (3) of the Agreement between the United Kingdom of Great Britain and Northern Ireland and Bosnia and Herzegovina for the Promotion and Protection of the Investments, 2268 U.NT.S. no. 317, 25 July 2003. 
provisions therein), it can also be inferred that manoeuvring by wiling arbitrators to significantly depart from that would be constrained. ${ }^{34}$ The outlined scenarios are also moot for the purposes of out discussion, as the issue of the interaction between the MFN clause and procedural issues is directly governed by the applicable text in the treaty.

What follows as a logical conclusion is that different tribunals have employed different approaches to reach similar or diverging effects when deciding on the scope and effect of the MFN clause. The actual wording of the clause (when it leaves room for different interpretation) bore no great significance on the outcome of the proceedings. Based on the same BITs panels have produced arbitral awards that decided on the same issue in a completely opposite way. This suggest that tribunals and arbitrators would usually start with a preconceived idea as to what the parties to the BIT had in mind when they drafted the MFN clause and then come up with (more or less) plausible interpretation strategies to justify the view they affixed.

However, combined with the proper context, adequate application of the standards from the Vienna Convention on the Law of Treaties as well as systematic analysis of the BIT and proper balancing of the interests of both the investor and the host state, MFN clauses leave enough room for a fresh outlook on a dated topic.

\section{MFN - Modern Challenge to Multilateralization}

Implications of adopting a particular stance in interpreting the MFN clauses are always multifold. As seen from the Maffezini line of reasoning, the moment the door to anew interpretative alleyway is opened slightly, there is room for a flood to occur. This is problematic for states that are parties to bilateral treaties as MFN clauses are interpreted in a way that they serve as a multilateralization tool with no proper boundaries, making it hard for states to assess and predict their liability towards individual investors. ${ }^{35}$ Revisiting the interpretative stance is therefore one of the key questions when MFN clauses are concerned, and recent arbitral practice shows the narrowing of the gap.

The decision of the tribunal in Içkale Case $^{36}$ clearly limited the claimant in the proceedings to rely on the MFN to invoke investment treaty standards of

34 See E. Gaillard, op.cit, 3.

35 Catherine Titi, "Most-Favoured-Nation Treatment, Survival Clauses and Reform of International Investment Law", Journal of International Arbitration Vol 5, No. 33, 2016, 425.

36 İçkale İnşaat Limited Şirketi v. Turkmenistan, ICSID Case No. ARB/10/24, Award 8 March, 2016 [hereinafter İçkale Case].. 
protection from another investment treaty. The approach was heralded as a shift from the "top-down" approach to a more "bottom-up" logic - instead of presuming that there is an overarching consensus of what an MFN clause means, one should investigate a particular case, particular treaty, and a specific set of circumstances of an individual case. Reflecting on the wording of the MFN clause from the BIT in question, the Tribunal in Içkale Case concluded:

"The terms "treatment accorded in similar situations" therefore suggest that the MFN treatment obligation requires a comparison of the factual situation of the investments of the investors of the home State and that of the investments of the investors of third States, for the purpose of determining whether the treatment accorded to investors of the home State can be said to be less favorable than that accorded to investments of the investors of any third State. It follows that, given the limitation of the scope of application of the MFN clause to "similar situations," it cannot be read, in good faith, to refer to standards of investment protection included in other investment treaties between a State party and a third State."

The important quantifier often neglected by the tribunals is that BIT arrangements are amendable only if the states, parties to it, sit down for the negotiating table. It is in this spirit of carelessness that tribunals often overstep the boundaries by employing MFN treatment to go beyond the confines of what was intended by the parties, and the objections that were raised by the Government of Turkmenistan in the case - and that eventually led to a decision of the tribunal not to allow importation of substantive standards from other international treaties - clearly demarcate a novel approach. As aptly stated in a recent commentary by Batifort and Heath, the award in Içkale Case could be understood to express "readiness among some arbitrators to reconsider more fundamentally the top-down approach to MFN, bracketing broad notions as to the "essence" of MFN provisions and choosing instead to proceed with the goal of giving effect to the specific provisions of individual MFN clauses." 37

When comparing the Maffezini logic of broad, over-arching setting of the MFN standard in 2000's and the narrow, case-specific approach by the tribunal in Içkale Case from 2016 one can make a few polarizing observations. Firstly, the practice of investment tribunals in applying adequate interpretative tools, is to

37 Simon Batifort., J. Benton Heath. "The New Debate on the Interpretation of MFN Clauses in Investment Treaties: Putting the Brakes on Multilateralization", American Journal of International Law, Vol. 11, No. 4, 2016, 899. 
say at least, inconsistent. Secondly, this leads to divergence, that in turn opens a series of questions for the states concluding BITs - how to limit the scope in a bilateral relationship and still provide a notion of most-favored nation in the wording of the agreement, without compromising what could be reasonably expected under the BIT. Finally, there are opposed schools of thought in interpretation of MFN clauses - "top down" vs "bottom up" - but these are on a sliding scale that depending on the time and circumstances can tip towards more restrictive or more open approach.

\section{CONCLUDING REMARKS}

States and investors engage in relations hoping for the best to come from the venture. Sometimes that relationship ends up in a happily ever after scenario (in which case we rarely have troublesome spotlight of the arbitration community) and in those other times in an "investment" divorce or even bankruptcy. The latter scenario, albeit somewhat dark and burdensome, will usually entail a set of negotiations with an aim to remedy the tragic consequences of the failed venture and most frequently a dispute before an international arbitral tribunal. This is the particular point in an investor-state relationship that opens numerous issues from the perspective of legal scholarship and practice, most intriguing topical issues arise within the context of an investment dispute when unsettled factual scenarios engage in interaction with legal standards and their interpretation.

The issue of MFN clauses and their application is a diverse one. There are many paths that practitioners and scholars take and explore; however, time and need for more balanced interpretation, focused and clear delimitation of the standards has shown that some of the busiest roads used may not be the proper ones. The fluidity and liberal approach to interpretation of the clauses in a BIT - such is the MFN treatment provision - has led to some imbalanced and shaky decisions that unfortunately stand as landmarks for practice.

One of the key problems in the current state of affairs is that practitioners and arbitrators tend to forget the decades of existence of the standard and the uniform application by international tribunals and courts from early $20^{\text {th }}$ century till 2000 as well as rules on interpretation from the Vienna Convention on the Law of Treaties. In addition, as MFN interpretation in disputes is usually colored with a pro-investor bias - extensive usage and expansion of the borders of the BIT has been a constant occurrence. This signals the need to revisit and re-think the concept of the MFN and go back to the application of the standard, as it was when its 
basic notion was reciprocity. Keeping this spill over to practice and case law could in a final instance result in better quality of decision making by arbitrators that is case-specific and contextual for a particular BIT and a particular dispute.

UROŠ ŽIVKOVIĆ, LL.M. (Cantab)

Savetnik za projekat cirkularne migracije

pri Programu Ujedinjenih nacija za razvoj

\section{INVESTICIONA ARBITRAŽA I PROBLEM NAJPOVLAŠĆENIJE NACIJE - TRNOVIT PUT OD ODLUKE MAFEZINI DO SLUČAJA IČKALE}

\section{Rezime}

Interpretacija klauzule najpovlašćenije nacije (MFN) u investicionoj arbitraži u fokusu je doktrinarne debate već duže od dve decenije. Ovaj rad istražuje pitanje tumačenja ove klauzule iz dva potpuno drugačija ugla - širokog pristupa zastupljenog u odluci arbitraže u slučaju Mafezini i novijeg, restriktivnog pristupa koji je primenio tribunal u Ičkale arbitražnom slučaju, sa ciljem da se, u najširim crtama, prikaže kako je moguće uspostaviti balansirani mehanizam u tumačenju ove sporne odredbe međunarodnog sporazuma o zaštiti stranih ulaganja.

Ključne reči: investiciona arbitraža, MFN, BIT, Maffezini

\section{Bibliography}

Acconci P., "Most-Favored-Nation Treatment", The Oxford Handbook of International Investment Law (Eds. Peter Muchlinski, Federico Ortino, Christoph Schreuer), Oxford, 2008.

Bagwellm K., Staiger, R.W., "Multilateral trade negotiations, bilateral opportunism and the rules of GATT/WTO”, Journal of International Economics, Vol. 63, Issue 1, 2004.

Banifatemi Y., "The Emerging Jurisprudence on the Most-Favoured-Nation Treatment in Investment Arbitration", Investment Treaty Law: Current Issues III: Remedies in International Investment Law: Emerging Jurisprudence of International Investment Law (Eds. A. K. Bjorklund, I. A. Laird, S. Ripinsky), British Institute of International and Comparative Law, London 2008.

Batifort S., Heath J.B., "The New Debate on the Interpretation of MFN Clauses in Investment Treaties: Putting the Brakes on Multilateralization", American Journal of International Law, Vol. 11, No. 4, 2016.

Dolzer R., Schreuer C., Principles of International Investment Law, Oxford, 2012.

Douglas Z., "The MFN Clause in Investment Arbitration: Treaty interpretation Off the Rails", Journal of International Dispute Settlement, Vol. 2, No. 1, Oxford, 2011.

Douglas Z., The International Law of Investment Claims, Cambridge, 2009. 
Fietta S., "Most Favored Nation Treatment and Dispute Resolution under Bilateral Investment Treaties: A Turning Point?”, International Arbitration Law Review, No. 4, 2005.

Freyer D.H., Frelihy D., "Most-Favored-Nation Treatment and Dispute Settlement in Investment Arbitration: Just How "Favored" is "Most-Favored"?" ICSID Review - Foreign Investment Law Journal, Vol. 20, Issue 1, 2005.

Gaillard E., "Establishing Jurisdiction Through a Most-Favored-Nation Clause”, New York Law Journal, Vol. 233, No. 105, New York, 2005.

Mann H., von Moltke K., Petersen L.E., Cosbey A., IISD Model International Agreement on Investment for Sustainable Development: Negotiators' Handbook, Winnipeg, 2006.

Maupin J.A., "MFN-Based Jurisdiction in Investor-State Arbitration: Is There any Hope for a Consistent Approach?”, Journal of International Economic Law, Vol. 14, No. 1, Oxford, 2011.

Molinuevo M., "Post-establishment MFN and NT Obligations", Protecting Investment in Services: Investor-State Arbitration versus WTO dispute Settlement (Ed. Martin Molinuevo), Global Trade Law Series, Vol. 38, The Hague, 2011.

Newcombe A., Paradell L., "Chapter V - Most-Favored-Nation Treatment”, Law and Practice of Investment Treaties: Standards of Treatment, The Hague, 2009.

Pellet A., "2013 LALIVE Lecture - The Case Law of the ICJ in Investment Arbitration", ICSID Review, Vol. 28, No. 2, 2013.

Schill S.W., "Multilateralizing Investment Treaties through Most-Favored-Nation Clauses", Berkeley Journal of International Law, Vol. 27, No. 2, 2009.

Schreuer C., "Travelling the BIT Route of Waiting Periods, Umbrella Clauses and Forks in the Road", The Journal of World Investment and Trade, Geneva, 2004.

Schwarzenberger G., “The Most-Favoured Nation Standard in British State Practice”, British Yearbook of International Law, Vol. 22, No. 96, London, 1945.

Sornarajah M., The International Law on Foreign Investment, Cambridge, 2010.

Subedi S.P., International Investment Law - Reconciling Policy and Principle, Oxford \& Portland, 2008.

Titi C., "Most-Favoured-Nation Treatment, Survival Clauses and Reform of International Investment Law", Journal of International Arbitration Vol 5, No. 33, 2016.

Toye R., "Developing Multilateralism: The Havana Charter and the Fight for the International Trade Organization, 1947-1948", The International History Review, XXV. 2, 2003.

United Nation Conference on Trade and Development (UNCTAD), "Most-Favored-Nation Treatment", UNCTAD Series on Issues in International Investment Agreements II, Geneva, 2010.

United Nations Conference on Trade and Development (UNCTAD), "Most-FavouredNation Treatment", UNCTAD Series on Issues I International Investment Agreements I, New York, 1999. 
Ustor E., "First Report on the Most-Favoured Nation Clause", Yearbook of the International Law Commission, Vol. 2, UN Doc. A/CB.4SERA/1969/Add. 1, New York, 1969.

Van den Bossche P., Werner Zdouc W., The Law and Policy of the World Trade Organization, Cambridge, 2013.

Vandevelde K.J., Bilateral Investment Treaties: History, Policy and Interpretation, New York, 2010.

Datumi prijema i prihvatanja rada

Primljen: 12.10 .2021 .

Prihvaćen: 28.10.2021.

ORIGINALAN NAUČNI RAD 